Journal of Social Sciences 6 (3): 478-482, 2010

ISSN 1549-3652

(C) 2010 Science Publications

\title{
Monks' Health: Holistic Health Care Model by Community Participation
}

\author{
${ }^{1}$ Decha Buates, ${ }^{1}$ Songkoon Chantachon, ${ }^{1}$ Kosit Paengsoi and ${ }^{2}$ Anongrit Kangrang \\ ${ }^{1}$ The Research Institute of North Eastern Arts and Culture, \\ ${ }^{2}$ Department of Civil Engineering, Faculty of Engineering, \\ Maha Sarakham University, Maha Sarakham, Thailand
}

\begin{abstract}
Problem statement: Monks' health tended to be a continuous increased problem. They were groups who had limitations to access health services due to their monastic disciplines and their most importance for Buddhist institution. Without urgent solution, their normal way of life would have been affected. Approach: This research aimed to study current conditions and to develop monks' holistic health care models by community participation in central region of Thailand. The study was a qualitative research conducted in 9 temples; 3 temples in urban area, 3 in semi-urban area and 3 in rural area. Samples were 224 persons; consisted of monks, public health officers from Department of Religious Affairs, local administrative organizations and people; selected by purposive sampling method. Observation form, survey form, interview form, focus group discussion and workshop were used as research tools while data was analyzed by descriptive research. Results: The result founded that in former time culture of monks' health care was leaned on community, social, culture and tradition. People spoke in style of central Thai language and were in agricultural sector as well as had their belief in merit, sin and elder respect. Relation in communities was in form of generosity and living as similar as relatives. When some monk got sick, they would visit, take care and give foods and medicines. Most of medicines were household remedy and Thai herbal medicine that bought from drug stores in local market or grocery stores in village and monks were sent to hospital in case of severe illness. Temple was a part of community, so they had close relation. Nowadays people increasingly worked in manufactories that caused conflicts and alienations among them. Monks leaned on local markets for receiving foods offering and most of foods were cooked from flour, sugar, coconut milk and fat. These caused three-fourth of monks having chronic disease as diabetes, hypertension, high cholesterol and gout. They had behaviors on addicting to cigarette, coffee and energy drink. They had less exercise without annual health checkup. Their cells were non-hygienic with plenty of garbage, foods scrap and joss stick dust. They preferred to have medical care at private clinics than hospitals or public health centers due to long time waiting. There were some protections by local administrative organizations as pets' vaccination and using Tempos sand granule for eliminating mosquito larva. Severe mental health problems were not found. Conclusion/Recommendations: Related agencies with monks' holistic health care models by community participation in central region of Thailand were local administrative organizations, communities, government agencies, temples/clergies, provincial office of Buddhism and monks. Important activities were participative operations of all related sectors, monks' annual health checkup 1-2 times a year, temples medicine cupboard, monk health care fund, pets' vaccination, temple public health volunteer, monk exercise promotion, temple improvement with the 5-S activity and usage of temple as center for health care development.
\end{abstract}

Key words: Monks' health, chronic disease, non-hygienic, community participation, holistic health

\section{INTRODUCTION}

Nowadays, more than three-fourth of monks in Thailand were elder persons. Almost $20 \%$ of them were sick with chronic and congenital diseases as hypertension, diabetes, heart disease, high cholesterol with $54.5 \%$ and obesity with $43.6 \%$. An important cause came from low level of the health condition and foods that consisted of high coconut milk, fat, flour and sugar. Moreover, there were risk behaviors such as; smoking with $26-38 \%$ with its relative high level of prevalence rate in eastern region with $40.5 \%$ and central region with $40.2 \%$, more than $50 \%$ drank coffee 8 cups per day, seldom drank energy drink with $86.7 \%$

Corresponding Author: Decha Buates, The Research Institute of North Eastern Arts and Culture,

Maha Sarakham University, Maha Sarakham, 44000 Thailand Tel: +66-43-721686 


\section{J. Social Sci., 6 (3): 478-482, 2010}

and drank clean water less than 6 glasses per day. For aspect of mental health problems, it was found that monks had their problems on behaviors and had indications of psychiatric symptom with $50.49 \%$, more than $54.3 \%$ had high level of stress than normal and $8.7 \%$ needed to have treatment and most of them had no exercise.

Ministry of Public Health stipulated policy to provide all of 34,000 temples with "Temple Health Center" for take caring monks' health by supporting with blood pressure monitors, weight scales and household remedies as well as good environment around temples. These were for monks' adaptation to happily live with their communities. Furthermore, it also promoted some temples to be "Health Promotion Temple" by supporting communities and local administrative organizations to participate in monks' health care.

Previous operations of government sector on monks' health care could have not been resolved problems due to lacking of concrete participation of communities and local administrative organizations, integrated operations from related agencies both of government and private sector (Hathirat, 1983; Goslinga, 1998; Ramsay et al., 2000; Miller et al., 2009; Murthy, 2007). These effected to the development of sustainable health care by themselves and needed to have a research with objectives to study body of knowledge, current conditions and problems and to develop monks' holistic health care models by community participation in central region of Thailand.

This research aimed to study current conditions and to develop monks' holistic health care models by community participation in central region of Thailand. The study was a qualitative research conducted in 9 temples. Samples were 224 persons selected by purposive sampling method. Observation form, survey form, interview form, focus group discussion and workshop were used as research tools while data was analyzed by descriptive research.

\section{MATERIALS AND METHODS}

This study was a Research and Development ( $\mathrm{R}$ and D) by using qualitative research (Mokhtar et al., 2008; Schrapp and Al-Mutairi, 2010). Population and samples were all monks of 6 provinces in the central region of Thailand and selected by purposive sampling method. Sample related with this research were 244 persons consisted of 32 key informants, 114 casual informants and 48 general informants. Research areas were 9 temples in 3 provinces; Phra Nakhon Si Ayutthaya, Lop Buri and Sing Buri; with 3 temples for each both in rural and municipal area. Survey forms, observation forms, interview forms, focus group discussions and workshops were used as research tools. Data was collected from documents, research reports, laws, policies, strategies and field work data. Validity, reliability and triangulation were used to test all data and it was analyzed by conclusion, classification and comparison.

\section{RESULTS}

Body of knowledge and background of monk's health care: For general conditions of research area, it was found that most of temples were ancient ones, without any differences of physical condition, that established during the middle to late period of Ayutthaya Kingdom and had about 5-8 monks. Each temple had its management that controlled by an abbot as the supreme leader.

For surrounded communities, it was found that most of them were original settlements before or in the same time as temple establishment. They had their social, tradition, culture and language in central region style. Most of them were located on the basin and along the bank of Chao Phraya River and Lopburi River. People worked in agricultural sector as rice and vegetable growers. Social, culture and tradition of central region people was in form of separated living. Nowadays their occupations were changed from agricultural to manufacture sector as workers in factories.

Relation between communities and temples was good and temple was a part of community. Temples were established by people belief while abbot and monks came from villagers that tied their relationship as relatives.

Previous culture on monks' health care was leaned on their community because there were native people that had many of relatives in village or community around that temple. When some monk got sick, villagers would visit, take care and give foods and medicines. Most of medicines were household remedy and monks were sent to hospital in case of severe illness. Today related parties such as all levels of local administrative organization, communities and also villagers around temple had their participation with monks' health care in very low level.

Current conditions and problems of monks' health care: In case of illness, monks had their medical care at private clinics because quick services than government services. There were very low level of health promotion and their daily activities were walking for food offering 
in the morning, sweeping temple court, grass cutting with 30-45 min per day. Disease protection in temples was duty of local administration organizations as using Tempos sand granule for killing mosquito larva and pets' vaccination. For rehabilitation, it was found that monks with chronic disease and defected movement were not monitored or visited from related agencies. There was lacking of continuous medication, physiotherapy and attendance form their relatives and other monks. Mental health problems were not found in these monks.

For social health care, it was found that there was not clear role in monks' health care among related agencies and left most of them took care by themselves.

For environment in temples, it was found that their cells were non-hygienic with plenty of garbage, foods scrap, joss stick and mosquito-repellent dust as well as scrap of dried flowers. Their clothes were not tidily kept. Most of their daily foods were flour, sugar, coconut milk and fat with hot taste and in high quantity.
Bottled drinking water, tap water and ground water were used for their consumption.

Proper monks' holistic health care models: The models with community participation in central region should have related agencies as local administrative organizations, communities, government agencies, temple/clergies and Office of Buddhism to do these following operations: (1) Promotion all temples to be center of rural development, (2) Planning of monks' health promotion, (3) Providing of temple medicine cupboard, (4) Setting of annual health checkup for 1-2 time a year, (5) Hydrophobia vaccination for dogs and cats in temples, (6) Appointment of integrated working groups, (7) Establishment of monks' health care fund, (8) Developing monks to be public health volunteers in temples, (9) Having public health volunteers in temples, (10) Conducting the 5-S activities in temples, (11) Participation of temples, houses, schools and local administrative organizations and (12) Setting daily exercise. These relationships are shown in Fig. 1.

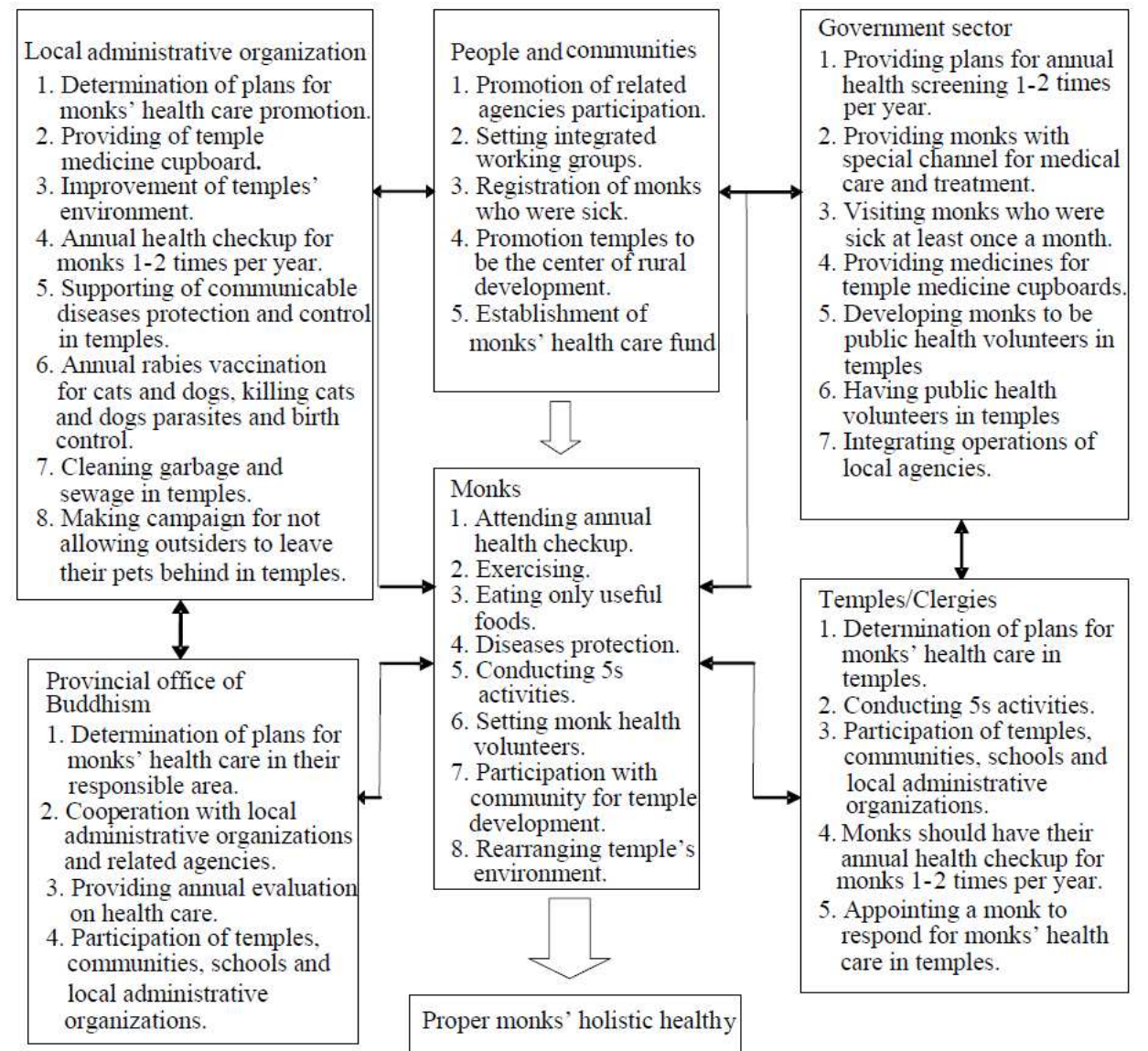

Fig. 1: Monks' health: holistic health care model by community participation in central region of Thailand 


\section{J. Social Sci., 6 (3): 478-482, 2010}

\section{DISCUSSION}

Nowadays problem on monks' health care was entering into critical stage. More than three-fourth of monks had their own chronic disease at least one disease for each. Most of such disease was diabetes, hypertension, high cholesterol and gout. Most of patients were elder monks that usually had their congenital diseases. Foods that offered by villagers were consisted of high flour, sugar and fat that harmed to their bodies especially in those who got some disease.

Access to health care services was difficult for monks than other ordinary people. All of public health center did not separate them from people; they had to wait for their queue together with people. They, therefore, preferred to have medical care at private clinics or hospitals instead due to more rapidness and convenience. Moreover, monks also lacked of attentions from relatives, people and other monks that caused from conflict on monks governance system and lots of people's faith. Meanwhile, monks themselves did not want to disturb people or other monks so they did not ask for help when they were sick. These indicated regression of relationship among temples, monks and communities that was very different from the past (Napoli, 2002).

Related agencies still had not enough activities on monks' health care. Most of them were only n exercise promotion as walking for food offering in the morning and sweeping temple court. Main factor or cause of less exercise was their elderliness that made reduction of exercise or other activities of health care promotion. So it was a must to place importance on health care promotion and arouse them to perceive their own competencies for protecting themselves from diseases by exercising and had awareness on diseases as subsequences of non-exercise.

For aspect of disease protection both of communicable and non-communicable diseases, temples and monks faced with this problem especially increasing of dogs and cats in temples. Almost of this problem caused by outsiders who left their pets behind in temples and they were rapidly bred. These were burdens of monks to feed, vaccinate and control them. This kind of management, then, was a new duty of local administrative organization.

Because of their elderliness and congenital diseases, changes of age and body condition made monks needed to be under some medical care. Relationship among temples, communities and monks was a reason for visiting monks who were sick. This was opposed to Buddhist teaching in regulation of monks' duties for visiting other who was sick as moral supporting. There were many incidents in the past that Buddha visited his disciples who was sick such as Phra Assachi, Phra Kemmaka, Phra Maha Kassapa and also new monks. This made monks had to follow all of their lives in monkhood and if they ignored it would cause problem of mental health.

The most environmental problem affected to monks was their cells were non-hygienic with plenty of garbage as plastic bags, water bottles, milk boxes and bottles of energy drink. They were also dust form joss stick and mosquito-repellent spread over their cells. Their clothes were not tidily kept. These were opposed to Buddhist teaching that they must usually keep clean on their rooms as well Buddha image hall and sermon hall or any kinds of religious buildings.

Related agencies on monks' health care; public health centers, local administrative organizations and communities; had no direct plans, projects or activities related with monks' health care such as health screening and visiting monks with chronic disease. Even though Ministry of public health, by Department of Health, had its project of Health Promotion Temple but it was conducted in only some temple. There was no policy for guiding temples to cooperate with related agencies. Data from this study indicated that integrated working system was still not been established on monks health care. This caused no one knew who was the main host of this matter among clergies, provincial office of Buddhism, all levels of public health agency, local administrative organizations or communities.

Monks' holistic health care models by community participation in central region of Thailand needed to have a national health screening system, provide them with special channel for accessing medical treatment at hospitals or public health centers and continuously visit monks who were sick by stimulating them to have awareness of risky behaviors that harmed to their health.

However, monks should be promoted with exercise by walking for food offering in every morning at least 3 days a week with duration of 30 min per day, body stretching by sweeping temple court at least $30 \mathrm{~min}^{-1} \mathrm{~h}$ $\mathrm{day}^{-1}$. Communicable diseases protection in all temples should be conducted with Hydrophobia vaccination for dogs and cats in temples, using Temephos sand granule for killing mosquito larva or eliminating sources of them and did not allow outsiders for leaving their pets behind in temples. Monks' self-health care for avoiding communicable diseases, they should have hygienic practices as eating hot foods, using separated spoons, washing hands for eating, no smoking, no energy drinks consumption, drinking clean water 6-8 glasses per day, 
sleeping 6-8 $\mathrm{h} \mathrm{day}^{-1}$, having continuous visiting those who were sick by their relatives, other monks and their abbots, providing annual health screening and frequent monitoring their symptoms that made them feel relieve.

\section{CONCLUSION}

The purpose of this study was to study current conditions and to develop monks' holistic health care models by community participation in central region of Thailand. The observation form, survey form, interview form, focus group discussion and workshop were used as research tools while data was analyzed by descriptive research. The result founded that monks' health care from outer social should be conducted by bring temples back as community center. Monks' health care must have come from participation of all relates parties by searching problems, planning and evaluation. Working by committees should be done for operation on monks' health care and social structure should be appropriately provided in that social context to completely solve conflicts from the past. Monks' health care in aspect of environment should be specially focus on their residences called "Kutti" (cell) that lacked of cleanliness and tidiness that opposed to Buddhist teaching. Activities on keeping their cells clean as a routine should be promoted.

\section{ACKNOWLEDGEMENT}

The researchers would like to express their appreciation to the Research Institute of North Eastern Arts and Culture, Maha Sarakham University, Maha Sarakham, Thailand.

\section{REFERENCES}

Goslinga, L.D., 1998. Thai monks and lay nuns (mae chii) in urban health care. Anthropol. Med., 5: 5-21. DOI: $10.1080 / 13648470.1998 .9964546$

Hathirat, S., 1983. Buddhist monks as community health workers in Thailand. Soc. Sci. Med., 17: 1485-1487. DOI: $10.1016 / 0277-$ 9536(83)90047-3

Miller, W.J., A.T. Sumner and R.H. Deane, 2009. Assessment of quality management practices within the healthcare industry. Am. J. Econ. Bus. Admin., 1: 105-113. DOI: 10.3844/.2009.105.113

Mokhtar, M.B., M.F. Al Ajlouni and R. Elfitrie, 2008. Integrated water resources management improving Langat basin ecosystem health. Am. J. Environ. Sci., 4: 380-382. DOI: 10.3844/.2008.380.382

Murthy, V.N.R., 2007. Income distribution and health status: Econometric evidence from OECD countries. Am. J. Applied Sci., 4: 192-196. DOI: 10.3844/.2007.192.196

Napoli, M., 2002. Holistic health care for native women: An integrated model. Am. J. Public Health, 92: 1573-1575. PMCID: PMC1447281

Ramsay, C.R., A.M. Grant, S.A. Wallace, P.H. Garthwaite and A.F. Monk et al., 2000. Assessment of the learning curve in health technologies. Int. J. Technol. Assess. Health Care, 16: 1095-1108. DOI: $10.1017 / \mathrm{S} 0266462300103149$

Schrapp, K. and N. Al-Mutairi, 2010. Associated health effects among residences near Jeleeb Al-Shuyoukh landfill. Am. J. Environ. Sci., 6: 184-190. DOI: 10.3844/.2010.184.190 